THE TAUBMAN PROFESSORSHIP AND LECTURES

The Herman P. and Sophia Taubman Visiting Professorship in Jewish Studies was established at the University of California, Berkeley, in 1975 by grants from Milton I. Taubman and the Taubman Foundation; an equal sum was contributed by the families of Maurice Amado, Walter A. Haas, Daniel E. Koshland, Madeleine Haas Russell, and Benjamin H. Swig. Distinguished scholars in the fields of Jewish studies are invited to teach at Berkeley for the enrichment of students and to give open lectures for the benefit of the public at large. Publication of the lectures is made possible by a special gift of the Taubman Foundation. 
This Page Left Intentionally Blank 
Halakhah in the Making 
THE TAUBMAN LECTURES IN JEWISH STUDIES

Daniel Boyarin, Series Editor

I. Biblical Prose Prayer as a Window to the Popular Religion of Ancient Israel, by Moshe Greenberg

2. Hebrew Poetry of the Middle Ages and the Renaissance, by Dan Pagis

3. The Promise of the Land: The Inheritance of the Land of Canaan by the Israelites, by Moshe Weinfeld

4. Tales of the Neighborhood: Jewish Narrative Dialogues in Late Antiquity, by Galit Hasan-Rokem

5. Alef, Mem, Tau: Kabbalistic Musings on Time, Truth, and Death, by Elliot Wolfson

6. Halakhah in the Making: The Development of Jewish Law from Qumran to the Rabbis, by Aharon Shemesh 


\title{
Halakhah in the Making
}

The Development of Jewish Law from Qumran to the Rabbis

\author{
Aharon Shemesh
}

UNIVERSITY OF CALIFORNIA PRESS

Berkeley Los Angeles London 
University of California Press, one of the most distinguished university presses in the United States, enriches lives around the world by advancing scholarship in the humanities, social sciences, and natural sciences. Its activities are supported by the UC Press

Foundation and by philanthropic contributions from individuals and institutions. For more information, visit www.ucpress.edu.

University of California Press

Berkeley and Los Angeles, California

University of California Press, Ltd.

London, England

(C) 2009 by The Regents of the University of California

Library of Congress Cataloging-in-Publication Data

Shemesh, Aharon.

Halakhah in the making : the development of Jewish law from Qumran to the rabbis / Aharon Shemesh.

p. $\quad \mathrm{cm}$. - (The Taubman lectures in Jewish studies)

Includes bibliographical references and index.

IS BN 978-0-520-25910-2 (cloth : alk. paper)

I. Jewish law-History-To I5oo. 2. Qumran commu-

nity. 3. Dead Sea scrolls. 4. Rabbinical literature-History

and criticism. 5.5. Judaism-History-To 70 A.D. I. Title.

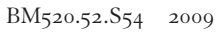

$296 . \mathrm{I}^{\prime} 80902-\mathrm{dc} 22$

2008051125

Manufactured in the United States of America

$\begin{array}{llllllllll}\text { I8 } & \text { I7 } & \text { I6 } & \text { I5 } & \text { I4 } & \text { I3 } & \text { I2 } & \text { II } & \text { IO } & 09\end{array}$

I0 $\quad 9 \begin{array}{lllllllll} & 8 & 7 & 6 & 5 & 4 & 3 & 2 & \text { I }\end{array}$

This book is printed on Cascades Enviro I0o, a roo\% post consumer waste, recycled, de-inked fiber. FSC recycled certified and processed chlorine free. It is acid free, Ecologo certified, and manufactured by BioGas energy. 
To my parents

Rachel and David Shemesh

"עוד ינובון בשיבה, דשנים ורעננים יהיו" (תהילים צב טו)

In old age they still produce fruits, they are full

of sap and freshness (Psalms, 92:15) 
This Page Left Intentionally Blank 